\title{
PENGARUH PEMAHAMAN, SANKSI PERPAJAKAN, DAN TINGKAT KEPERCAYAAN PADA PEMERINTAH TERHADAP KEPATUHAN WAJIB PAJAK DALAM MEMBAYAR PBB-P2 (Studi Empiris Wajib Pajak PBB-P2 Kecamatan Jatinegara)
}

\author{
Rahmat Yuliansyah $^{1}$, Desy Amaliati Setiawan ${ }^{2}$, Rayahu Sri Mumpuni ${ }^{3}$ \\ Sekolah Tinggi Ilmu Ekonomi Indonesia \\ Jl. Kayu Jati Raya No. 11A, Rawamangun - Jakarta 13220, Indonesia \\ desy.fanuc@yahoo.com ${ }^{1}$
}

\begin{abstract}
Abstrak - This research aims to knowing effect understanding tax, tax sanction, and level of trust in the goverment againts taxpayers compliance in paying land and building tax - rural and urban in the sub-district Jatinegara. The population in this research were PBB-P2 taxpayers registered in Jatinegara sub-district as many as 27,761 taxpayers. The sample in this study amounted to 100 taxpayers obtained from the results of calculations using the Slovin formula. The method of collecting data in this study by distributing questionnaires. Questionnaire tests in this research, namely data quality test, classic assumption test, and hypothesis test. The results of this research indicate that there is a significant effect of the understanding variable on taxpayer compliance in PBB-P2 payments. This is evidenced by the positive regression coefficient $(0.307)$ and tcount greater than the value of ttable $(4.408>1.98498)$ at the significance value $(0,000<$ $5 \%$ ). There is a significant effect of tax sanction variable on taxpayer compliance in PBB-P2 payments. This is evidenced by the negative regression coefficient $(-0.209)$ and tcount smaller than the value of ttable $(-1.452<1.98498)$ at the significance value $(0,150>5 \%)$. There is a significant effect of the level of trust in the government variable on taxpayer compliance in PBB-P2 payments. This is evidenced by the positive regression coefficient $(0.654)$ and tcount greater than the value of ttable $(6.540>1.98498)$ at the significance value $(0,000<$ $5 \%)$. Understanding, tax Sanctions, and the level of trust in the government have a significant effect of a manner together on taxpayers compliance in PBB-P2 payments. This is evidenced by the value of Fcount which is greater than the value of Ftable $(28,113>2,70)$ at the significance value $(0,000<5 \%)$.
\end{abstract}

Keywords : Compliance PBB-P2 Taxpayers, Understanding of Taxes, Tax Sanctions, Level of Trust in the Government 


\section{PENDAHULUAN}

Salah satu sumber pendanaan pembangunan ataupun perbaikan sarana dan prasarana dalam negeri yaitu melalui pajak yang dipungut oleh petugas pajak kepada wajib pajak. Karena pajak adalah suatu kewajiban wajib pajak kepada negara yang berlaku pada orang pribadi maupun badan yang bersifat memaksa tapi tetap sesuai dengan ketentuan yang ada dalam undang-undang yang berlaku di setiap negara dan tidak mendapatkan imbalan secara langsung karena dipakai untuk keperluan bersama dan kesejahteraan rakyat.

Pajak menurut Undang-Undang Nomor 6 tahun 2009 tentang perubahan keempat atas Undang-Undang Nomor 6 tahun 1983 tentang Ketentuan Umum dan Tata Cara Perpajakan pada pasal 1 ayat 1 yang berbunyi, Pajak adalah kontribusi wajib kepada negara yang terutang oleh orang pribadi atau badan yang bersifat memaksa berdasarkan Undang-Undang, dengan tidak mendapatkan imbalan secara langsung dan digunakan untuk keperluan negara bagi sebesar-besarnya kemakmuran rakyat. Pajak adalah prestasi yang dipaksakan sepihak oleh dan terutang kepada penguasa (menurut norma-norma yang ditetapkannya secara umum), tanpa adanya kontraprestasi, dan semata-mata digunakan untuk menutup pengeluaran-pengeluaran umum (Dr. N. J. Feldmann dalam Resmi, 2017:1).

Dalam meningkatkan penerimaan pajak Pemerintah melakukan berbagai cara. Berdasarkan lembaga pemungutannya di Indonesia pajak di bedakan menjadi dua (2) yaitu Pajak Daerah dan Pajak pusat. Pajak Daerah adalah kontribusi wajib pajak kepada daerah yang terutang oleh orang pribadi ataupun badan yang bersifat memaksa berdasarkan undang-undang dengan tidak mendapatkan imbalan secara langsung dan digunakan untuk keperluan daerah bagi sebesar-besarnya kemakmuran rakyat (www.online-pajak.com). Pajak Pusat adalah pajak yang dikelola oleh pemerintah pusat (Direktorat Jenderal Pajak) dan hasilnya dipergunakan untuk membiayai pengeluaran rutin negara dan pembangunan (APBN) (www.bprd.jakarta.go.id).

Perkembangan PBB sektor pedesaan dan perkotaan menjadi pajak daerah yang diatur dalam Undang-Undang No. 28 Tahun 2009 tentang Pajak Daerah dan Retribusi Daerah (PDRD) Pasal 77 sampai dengan pasal 84 mulai tahun 2010. Dalam Bab I diatur tentang Ketentuan Umum yang memberikan penjelasan tentang istilah-istilah teknis atau definisi-definisi Pajak Bumi dan Bangunan (PBB) seperti pengertian : 
1. Bumi adalah permukaan bumi dan tubuh bumi yang ada dibawahnya. Pengertian tersebut artinya bahwa bukan hanya tanah permukaan bumi saja tetapi benarbenar bumi dari permukaan sampai dengan magma, hasil tambang, gas material yang lainnya.

2. Bangunan adalah konstruksi teknik yang ditanam atau dilekatkan secara tetap pada tanah dan/atau perairan.

Dalam meningkatkan penerimaan Pajak Bumi dan Bangunan (PBB) perlu adanya peningkatan tingkat kesadaran dan kepedulian pada masyarakat di bidang perpajakan. Sistem Pemungutan Pajak yang digunakan dalam membayar Pajak Bumi dan Bangunan (PBB) adalah Official Assessment System, sistem pemungutan tersebut dimana jumlah pajak yang harus dilunasi atau terutang oleh wajib pajak dihitung dan ditetapkan oleh fiskus atau aparat pajak (Jati, 2016).

Berdasarkan uraian pada Latar Belakang diatas peneliti merasa tertarik dan termotivasi untuk melakukan penelitian di wilayah yang berbeda dan dibukukan dalam bentuk skripsi yang berjudul "Pengaruh Pemahaman, Sanksi Perpajakan, dan Tingkat Kepercayaan Pada Pemerintah Terhadap Kepatuhan Wajib Pajak Dalam Membayar PBB-P2".

\section{Rumusan Masalah :}

1) Apakah Pemahaman Perpajakan berpengaruh terhadap Kepatuhan Wajib Pajak dalam Membayar PBB-P2 (Studi Empiris pada Wajib Pajak PBB-P2 Kecamatan Jatinegara)?

2) Apakah Sanksi Perpajakan berpengaruh terhadap Kepatuhan Wajib Pajak dalam Membayar PBB-P2 (Studi Empiris pada Wajib Pajak PBB-P2 Kecamatan Jatinegara)?

3) Apakah Tingkat Kepercayaan Pada Pemerintah dan Hukum berpengaruh terhadap Kepatuhan Wajib Pajak dalam Membayar PBB-P2 (Studi Empiris pada Wajib Pajak PBB-P2 Kecamatan Jatinegara)?

4) Apakah Pemahaman Perpajakan, Sanksi Perpajakan, dan Tingkat Kepercayaan Pada Pemerintah dan Hukum berpengaruh terhadap Kepatuhan Wajib Pajak dalam Membayar PBB-P2 (Studi Empiris pada Wajib Pajak PBB-P2 Kecamatan Jatinegara)?

\section{LANDASAN TEORI DAN PENGEMBANGAN HIPOTESIS}

Pemahaman peraturan perpajakan adalah suatu proses dimana wajib pajak memahami dan mengetahui tentang peraturan dan Undang-undang serta tata cara 
perpajakan yang berlaku dan menerapkannya untuk melaksanakan kegiatan perpajakan seperti, membayar pajak tepat waktu, melaporkan SPT, dan lain sebagainya. Jika seseorang telah memahami dan mengerti tentang peraturan perpajakan maka secara otomatis kepatuhan wajib pajak dalam membayar pajak akan meningkat (Adiasa, 2013 dalam Wijayanti dan Sasongko, 2017).

(Yusnindar dkk, 2015) Sanksi pajak merupakan salah satu faktor yang dapat mempengaruhi kepatuhan wajib pajak dalam membayar pajak, karena fungsi pajak adalah sebagai alat untuk mengatur sekelompok orang untuk memenuhi aturan yang telah ditetapkan.Sanksi pajak diperuntukan kepada wajib pajak yang melanggar peraturan perpajakan yang berlaku sekarang. Dengan adanya sanksi pajak berupa denda maupun pidana yang cukup besar maka diharapkan wajib pajak lebih mentaati dalam hal pemabayaran PBB.

Menurut Mardiasmo (2018:62), sanksi perpajakan merupakan jaminan bahwa ketentuan peraturan perundang- undangan perpajakan (norma perpajakan) akan dituruti/ditaati/dipatuhi. Atau bisa dengan kata lain sanksi perpajakan merupakan alat pencegah (preventif) agar wajib pajak tidak melanggar norma perpajakan.

Dan menurut Soemarso (2013:169) sanksi perpajakan merupakan hukum pajak yang pada hakikatnya mengatur hubungan antara rakyat (wajib pajak) dengan negara (pihak pajak). Di dalam hukum pajak diatur hak dan kewajiban wajib pajak serta pihak pajak. Agar undang-undang dapat secara efektif dilaksanakan, setiap aturan tentang kewajiban harus ada sanksinya, jika kewajiban tersebut tidak dipatuhi.

Menurut Kamus Besar Bahasa Indonesia (KBHI, 2018) yang dimaksud dengan kepatuhan adalah ketaatan dalam menjalankan aturan-aturan yang telah ditetapkan. Mardiasmo (2018:27) mendefinisikan wajib pajak adalah orang pribadi atau badan, meliputi pembayaran pajak, pemotong pajak, dan pemungut pajak, yang mempunyai hak dan kewajiban perpajakan sesuai dengan ketentuan peraturan perundang-undangan perpajakan. Kepatuhan wajib pajak sebagai suatu keadaan dimana wajib pajak memenuhi semua kewajiban perpajakan dan melaksanakan hak perpajakannya (Wijayanti dan Sasongko, 2017). Ramadiansyah, a dkk, (2014) kepatuhan perpajakan diartikan sebagai suatu keadaan yang mana wajib pajak patuh dan mempunyai kesadaran dalam memenuhi kewajiban perpajakan. 
Menurut Mardiasmo (2018:4) Ada dua fungsi pajak, yaitu :

a) Fungsi anggaran (budgetair)

Pajak berfungsi sebagai salah satu sumber dana bagi pemerintah untuk membiayai pengeluaran-pengeluarannya.

b) Fungsi mengatur (cregulerend)

Pajak berfungsi sebagai alat untuk mengatur atau melaksanakan kebijaksanaan pemerintah dalam bidang sosial dan ekonomi.

Berdasarkan uraian yang telah dijabarkan diatas, maka berikut ini adalah beberapa penelitian yang membahas tentang faktor-faktor apa saja yang mempengaruhi wajib pajak dalam kepatuhan membayar PBB-P2. Penelitian mengenai pemahaman wajib pajak yang dilakukan oleh Purnamasari (2016), menyatakan bahwa pemahaman berpengaruh terhadap kepatuhan wajib pajak membayar PBB. Berbeda dengan hasil penelitian dari Faizin, dkk (2016), menyatakan bahwa pemahaman tidak berpengaruh siginifikan terhadap kepatuhan wajib pajak membayar PBB.

Penelitian mengenai sanksi perpajakan yang dilakukan oleh Widiastuti dan Laksito (2014), menyatakan bahwa sanksi perpajakan tidak berpengaruh terhadap kepatuhan wajib pajak membayar PBB. Sedangkan menurut penelitian Wijayanti dan Sasongko (2017), menyatakan bahwa sanksi perpajakan berpengaruh terhadap kepatuhan wajib pajak membayar PBB.

Penelitian mengenai tingkat kepercayaan pada pemerintah dan hukum yang dilakukan oleh Purnamasari (2016), menyatakan bahwa tingkat kepercayaan pada pemerintah dan hukum tidak berpengaruh terhadap kepatuhan wajib pajak membayar PBB. Sedangkan menurut penelitian Suyono (2016), menyatakan bahwa tingkat kepercayaan pada pemerintah dan hukum berpengaruh terhadap kepatuhan wajib pajak membayar PBB

\section{METODE PENELITIAN}

\subsection{Strategi Penelitian}

Penelitian ini merupakan penelitian asosiatif, yang mana penelitian ini merupakan penelitian yang memiliki tujuan untuk mengetahui hubungan ataupun pengaruh terhadap variabel yang satu dengan yang lainnya. Pemilihan strategi ini agar dapat menjelaskan seberapa besar pengaruh pemahaman, sanksi perpajakan, serta tingkat kepercayaan pada pemerintah terhadap kepatuhan wajib pajak membayar PBB- 
$\mathrm{P} 2$. Jenis penelitian yang digunakan dalam penelitian ini adalah penelitian kuantitatif dengan menggunakan metode survei berupa penyebaran kuesioner kepada wajib pajak yang membayar PBB-P2 yang tercatat diKecamatan Jatinegara.

\subsection{Populasi dan Sampel}

\subsubsection{Populasi Penelitian}

Populasi adalah wilayah generalisasi yang terdiri atas: objek/subjek yang mempunyai kualitas dan karakteristik tertentu yang diterapkan oleh peneliti untuk dipelajari dan kemudian ditarik kesimpulannya (Sugiyono, 2017:80). Populasi yang terdapat dalam penelitian ini yaitu wajib pajak yang membayar PBB yang terdaftar diKecamatan Jatinegara. Yang terdaftar sebagai wajib pajak PBB-P2 diKecamatan Jatinegara sejumlah 27.761 wajib pajak (www.poskotanews.com).

\subsubsection{Sampel Penelitian}

Sampel adalah bagian dari jumlah dan karakteistik yang dimiliki oleh populasi tersebut (Sugiyono, 2017:81). Pengambilan sampel yang terdapat pada penelitian ini dengan menggunakan simple random sampling, dikatakan simple (sederhana) karena pengambilan anggota sampel dari populasi dilakukan secara acak tanpa memperhatikan strata yang ada dalam populasi itu (Sugiyono, 2017:82).

Sampel yang terdapat dalam penelitian ini diperoleh dengan menggunakan rumus slovin, yaitu:

$$
n=\frac{\mathrm{N}}{\left(1+N e^{2}\right)}
$$

Keterangan :

$n \quad=$ Saampel

$\mathrm{N} \quad=$ Populasi

$\mathrm{E} \quad=$ Tarif Kesalahan atau nilai krisis

Penelitian ini dilakukan dengan mengambil sampel pada tingkat kepercayaan $90 \%$ atau nilai kritis $10 \%$ dengan pertimbangan nilai kritis tersebut digunakan dalam penelitian terdahulu. Sesuai rumus diatas, maka jumlah sampel yang akan digunakan dalam penelitian ini adalah sebagai berikut:

$$
\begin{gathered}
n=\frac{27.761}{\left(1+27.761\left(0,1^{2}\right)\right)} \\
n=99,64
\end{gathered}
$$


Berdasarkan perhitungan yang tertera diatas maka jumlah sampel yaitu 99,64 maka untuk mempermudah dalam perhitungan berikutnya hasil dari perhitungan dibulatkan menjadi 100. Dengan demikian dalam penelitian ini menggunakan 100 responden wajib pajak yang membayar PBB-P2.

\subsection{Data dan Metoda Pengumpulan Data}

\subsubsection{Data Primer}

Data primer mengacu pada informasi yang diperoleh langsung (dari tangan pertama) oleh peneliti terkait dengan variabel ketertarikan untuk tujuan tertentu dari studi (Sekaran, 2017:130). Sumber data primer yang digunakan dalam penelitian ini diperoleh secara langsung dari pihak wajib pajak yang membayar PBB-P2 yang tercatat diKecamatan Jatinegara. Data primer ini berupa kuesioner yang telah diisi oleh pihak wajib pajak PBB-P2 yang menjadi responden terpilih pada penelitian ini.

\subsubsection{Data Sekunder}

Data Sekunder mengacu pada informasi yang dikumpulkan dari sumber-sumber yang sudah ada (Sekaran, 2017:130). Sumber data sekunder yang digunakan dalam penelitian ini diperoleh melalui media perantara yaitu buku-buku, jurnal, website, dan lain sebagainya yang isinya berkaitan dengan perpajakan.

\subsubsection{Metoda Pengumpulan Data}

Teknik pengumpulan data yang dilakukan pada penelitian ini yaitu metode survei. Metode survei merupakan metode untuk melakukan pengumpulan data primer yang menggunakan pertanyaan lisam maupun tulisan (Supomo, 2009:152). Pada penelitian ini peneliti menyebar kuesioner kepada pihak wajib pajak yang membayar PBB-P2 diKecamatan Jatinegara agar dapat menjelaskan hubungan-hubungan yang terdapat pada ketiga variabel (X) terhadap satu variabel $(\mathrm{Y})$ yang akan diteliti. Pada kuesioner yang diberikan kepada wajib pajak yang membayar PBB-P2 yang menjadi responden, dalam mengukur instrumen pada variabel-variabel penelitian ini, digunakan skala likertdengan rentang 1 sampai dengan 4. Kriteria yang digunakan antara lain sebagai berikut:

a. Jawaban Sangat Setuju (SS) mendapat nilai (1)

b. Jawaban Setuju (S) mendapat nilai (2)

c. Jawaban Tidak Setuju (TS) mendapat nilai (3)

d. Jawaban Sangat Tidak Setuju (STS) mendapat nilai (4) 
Metode survei dengan menyebar kuesioner ini digunakan agar peneliti dapat mengetahui dan mempunyai data tentang penilaian yang diberikan oleh wajib pajak yang membayar PBB-P2 untuk berikutnya dapat menarik kesimpulan dalam hasil penelitiannya.

\subsection{Operasionalisasi Variabel}

\subsubsection{Variabel Independen}

Variabel independen sering disebut juga sebagai variabel stimulus, prediktor, antecedent. Dalam bahasa Indonesia sering disebut sebagai variabel bebas. Variabel bebas adalah variabel yang mempengaruhi atau yang menjadi sebab perubahannya atau timbulnya variabel dependen (terikat) (Sugiyono, 2017:39).

\subsubsection{Variabel (X1) Pemahaman Perpajakan}

Variabel independen pertama (X1) yaitu pemahaman perpajakan adalah pengetahuan dan pikiran Wajib Pajak atas kewajiban perpajakannya untuk memberikan kontribusi kepada Negara dalam memenuhi keperluan pembiayaan dan pembangunan nasional guna tercapainya keadlian dan kemakmuran (Agustiningsih, 2016). Instrumen yang digunakan untuk mengukur variabel pemahaman perpajakan diadopsi dari Agustiningsih (2016) terdapat 4 (empat) indikator, yaitu :

1. Pemahaman mengenai Ketentuan Umum dan Tata Cara Perpajakan;

2. Pemahaman mengenai undang-undang perpajakan di Indonesia;

3. Pemahaman mengenai fungsi perpajakan;

4. Pemahaman mengenai pengajuan keberatan perpajakan.

\subsubsection{Variabel (X2) Sanksi Perpajakan}

Variabel independen kedua (X2) yaitu sanksi perpajakan merupakan jaminan bahwa ketentuan peraturan perundang-undangan perpajakan (norma perpajakan) akan dituruti/ditaati/dipatuhi (Mardiasmo, 2018:62). Instrumen yang digunakan

untuk mengukur variabel kepatuhan wajib pajak diadopsi dari Redae dan Sekhon (2016) terdapat 3 (tiga) indikator, yaitu :

1. Sanksi perpajakan yang dikenakan bagi pelanggar aturan pajak cukup berat,

2. Pengenaan sanksi pajak yang cukup berat merupakan salah satu sarana untuk mendidik wajib pajak, dan

3. Sanksi pajak harus dikenakan kepada pelanggarnya tanpa toleransi 


\subsubsection{Variabel (X3) Tingkat Kepercayaan Pada Pemerintah}

Variabel independen ketiga (X3) yaitu kepercayaan pada pemerintah ialah mengukur tentang suatu hal yang diharapkan oleh wajib pajak dari sistem pemerintah yang berlaku berdasarkan nilai dan norma yang ada (Purnamasari, dkk 2016). Instrumen yang digunakan untuk mengukur variabel pemahaman perpajakan diadopsi dari Purnamasari (2016) terdapat 5 (lima) indikator, yaitu:

1. Kepercayaan pada pemerintah

2. Kepercayaan pada sistem hokum

3. Kepercayaan pada lembaga peradilan

4. Kepercayaan pada pemungutan pajak yang dialokasikan kembali ke rakyat

5. Percaya terhadap petugas pemungut pajak (fiskus)

\subsubsection{Variabel Dependen}

Variabel dependen sering disebut juga sebagai variabel output, kriteria, konsekuen. Dalam bahasa Indonesia sering disebut sebagai variabel terikat. Variabel terikat merupakan variabel yang dipengaruhi atau yang menjadi akibat, karena adanya variabel bebas (Sugiyono, 2017:39).

\subsubsection{Variabel (Y) Kepatuhan Wajib Pajak Membayar PBB-P2}

Variabel dependen yang digunakan pada penelitian ini adalah kepatuhan wajib pajak di Kecamatan Jatinegara. Kepatuhan Wajib Pajak adalah suatu keadaan dimana Wajib Pajak memenuhi segala kewajiban perpajakannya (Agustiningsih, 2016). Instrumen yang digunakan untuk mengukur variabel kepatuhan wajib pajak diadopsi dari Agustiningsih (2016) terdapat 4 (empat) indikator, yaitu :

1. Kepatuhan dalam mendaftarkan diri,

2. Kepatuhan dalam melaporkan kembali Surat Pemberitahuan (SPT),

3. Kepatuhan dalam perhitungan dan pembayaran pajak terutang, dan

4. Kepatuhan dalam pembayaran tunggakan pajak dan sanksinya. 
Tabel 3.1 Operasionalisasi Variabel

\begin{tabular}{|c|c|c|c|}
\hline No. & Variabel & Indikator & Kuesioner \\
\hline \multirow[t]{4}{*}{1.} & \multirow[t]{4}{*}{$\begin{array}{l}\text { Pemahaman } \\
\text { Perpajakan }\end{array}$} & $\begin{array}{l}\text { Pemahaman mengenai Ketentuan Umum dan } \\
\text { Tata Cara Perpajakan }\end{array}$ & $4,5,7,10$ \\
\hline & & $\begin{array}{l}\text { Pemahaman mengenai undang-undang } \\
\text { perpajakan di Indonesia }\end{array}$ & $1,2,3$ \\
\hline & & Pemahaman mengenai fungsi & 68,9 \\
\hline & & $\begin{array}{l}\text { perpajakanPemahaman mengenai pengajuan } \\
\text { keberatan perpajakan }\end{array}$ & \\
\hline \multirow[t]{3}{*}{2.} & \multirow[t]{3}{*}{ Sanksi Perpajakan } & $\begin{array}{l}\text { Sanksi perpajakan yang dikenakan bagi } \\
\text { pelanggar aturan pajak cukup berat }\end{array}$ & 1,2 \\
\hline & & $\begin{array}{l}\text { Pengenaan sanksi pajak yang cukup berat } \\
\text { merupakan salah satu sarana untuk mendidik } \\
\text { wajib pajak dan }\end{array}$ & $\begin{array}{l}3,4 \\
5\end{array}$ \\
\hline & & $\begin{array}{l}\text { Sanksi pajak harus dikenakan kepada } \\
\text { pelanggarnya tanpa toleransi }\end{array}$ & \\
\hline \multirow[t]{5}{*}{3.} & \multirow{5}{*}{$\begin{array}{l}\text { Tingkat Kepercayaan } \\
\text { Pada Pemerintah }\end{array}$} & Kepercayaan pada pemerintah & 1 \\
\hline & & Kepercayaan pada sistem hokum & \\
\hline & & Kepercayaan pada lembaga peradilan & 6,74 \\
\hline & & $\begin{array}{l}\text { Kepercayaan pada pemungutan pajak yang } \\
\text { dialokasikan kembali ke rakyat }\end{array}$ & 2,3 \\
\hline & & $\begin{array}{l}\text { Percaya terhadap petugas pemungut pajak } \\
\text { (fiskus) }\end{array}$ & 8 \\
\hline \multirow[t]{4}{*}{4.} & \multirow{4}{*}{$\begin{array}{l}\text { Kepatuhan Wajib Pajak } \\
\text { dalam Membayar PBB- } \\
\text { P2 }\end{array}$} & Kepatuhan dalam mendaftarkan diri & 8,9 \\
\hline & & $\begin{array}{l}\text { Kepatuhan dalam melaporkan Kembali Surat } \\
\text { Pemberitahuan (SPT) }\end{array}$ & \\
\hline & & $\begin{array}{l}\text { Kepatuhan dalam perhitungan } \text { dan } \\
\text { pembayaran pajak terutang dan }\end{array}$ & 4,7 \\
\hline & & $\begin{array}{l}\text { Kepatuhan dalam pembayaran tunggakan } \\
\text { pajak dan sanksinya }\end{array}$ & $1,5,62,3$ \\
\hline
\end{tabular}

\subsection{Metoda Analisis Data}

Metode yang digunakan pada penelitian ini yaitu metode kuantitatif. Metode kuantitatif dapat diartikan sebagai metode penelitian yang berlandaskan pada filsafat posotivisme, metode ini sebagai metode ilmiah/scientific karena telah memenuhi kaidah-kaidah ilmiah yaitu konkrit/empiris, obyektif, terukur, rasional, dan sistematis, 
dan hasil dari penelitian ini berupa angka-angka dan analisis menggunakan statistik (Sugiyono, 2017:7). Cara dalam pengolahan data ini peneliti melakukan penyebaran kuesioner dan hasil dari kuesioner yang telah diisi oleh para wajib pajak akan diproses melalui komputer dengan program SPSSversion-24.Penyajian data pada penelitian ini berupa tabel, pemilihan cara pengolahan data dengan SPSS version-24 itu bertujuan agar dapat mempermudah dan mempersingkat dalam penyajian data pada penelitian ini. Analisis regresi berganda digunakan pada penelitian ini untuk mengetahui ada tidaknya pengaruh tiga variabel independen terhadap satu variabel dependen.

\subsubsection{Uji Kualitas Data}

\subsubsection{Uji Validitas Data}

Pada uji validitas data dilakukan untuk dapat mengukur sah atau tidaknya suatu kuesioner (Wijayanti dan Sasongko, 2017). Suatu kuesioner dapat dinyatakan valid apabila pertanyaan yang tertera pada kuesioner dapat mengungkapkan sesuatu yang akan diukur oleh kuesioner tersebut (Ghozali, 2016:52). Dengan arti lain, uji validitas dapat digunakan untuk mengukur apakah pertanyaan yang ada pada kuesioner yang telah kita buat mampu mengukur apa yang akan kita ukur nanti. Dalam sebuah instrumen penelitian dapat dibilang valid jika memenuhi syarat sebagai berikut :

1. Jika $r$ hitung $>r$ tabel, maka dinyatakan valid

2. Jika $r$ hitung $<r$ tabel, maka dinyatakan tidak valid

Untuk menguji validitas yang ada pada kuesioner maka digunakan teknik korelasi product moment pearson.

$$
r_{x y}=\frac{n \Sigma X Y-(\Sigma X)(\Sigma Y)}{\sqrt{\left\{n \Sigma X^{2}-(\Sigma X)^{2}\right\}}\left\{n \Sigma Y^{2}-(\Sigma Y)^{2}\right\}}
$$

(Sugiyono, 2017:248)

Keterangan :

$\mathrm{r} \quad=$ koefisien korelasi Product Moment

$\mathrm{x}=$ jumlah skor untuk indikator $\mathrm{X}$

$\mathrm{y} \quad=$ jumlah skor untuk indikator $\mathrm{Y}$

$\mathrm{n} \quad=$ banyak responden (sampel) dari variabel $\mathrm{X}$ dan $\mathrm{Y}$

\subsubsection{Uji Reliabilitas}

Pada uji reliabilitas yang digunakan dalam penelitian ini berfungsi untuk mengukur kuesioner yang merupakan indikator dari variabel yang akan diteliti 
(Wijayanti dan Sasongko, 2017). Pengujian untuk mengetahui sejauh mana hasil pengukuran terhadap butir-butir pertanyaan apakah tetap konsisten bila dilakukan pengukuran dua atau lebih terhadap gejala yang sama dengan alat ukur yang sama (Ghozali, 2016:53). Reliabilitas instrumen penelitian diuji menggunakan rumus koefisien Cronbach's Alpha. Syarat untuk instrument dalam penelitian ini dapat dikatakan realible, apabila nilai koefisien alpha lebih besar dari 0,6 maka disimpulkan bahwa instrument penelitian tersebut handal atau reliable, dan berlaku sebaliknya apabila nilai koefisien alpha lebih kecil dari 0,6 maka butir tersebut tidak reliable (Ghozali, 2016:48). Berikut ini ialah rumus untuk menghitung reliabilitas, sebagai berikut :

$$
\text { ral }=\{N N-2\}\left\{1-\Sigma s^{2} t V t\right\}
$$

Keterangan :

ral = korelasi keandalan alpha

$\mathrm{N} \quad=$ jumlah responden

$\Sigma s^{2} \mathrm{t}=$ jumlah variasi bagian

$\mathrm{Vt}=$ varian total

\subsubsection{Uji Asumsi Klasik}

\subsubsection{Uji Multikolinearitas}

Pada uji multikolinearitas memiliki tujuan untuk menguji apakah dalam model regresi ditemukan adanya korelasi antar variabel independen (Y) (Ghozali, 2016:103). Dalam model regresi yang seharusnya tidak terjadi korelasi diantara variabel independen (Y). Nilai tolerance yang rendah sama dengan nilai VIF yang tinggi (karena $\mathrm{VIF}=1 /$ Tolerance). Dasar pengambilan keputusan yaitu apabila nilai tolerance $>0,1$ atau sama dengan nilai VIF $<10$ berarti tidak ada multikolinearitas antar variabel pada model regresi.

\subsubsection{Uji Heteroskedastisitas}

Untuk menguji apakah pada model regresi terjadi ketidaksamaan varians dari residual satu pengamatan ke pengamatan lainnya. Apabila varians dari residual satu pengamatan ke pengamatan lainnya tetap, maka hal itu disebut homoskedastisitas dan apabila varians tersebut berbeda maka hal itu disebut heteroskedastisitas. Model regresi yang baik ialah homokedastisitas (Ghozali, 2016:134). Untuk mendeteksi ada atau 
tidaknya heteroskedastisitas di dalam model regresi tersebut, dapat diidentifikasi dengan cara melihat grafik plot antara nilai prediksi variabel dependen (ZPRED) dengan residualnya (SRESID) dimana sumbu (Y) adalah yang telah diprediksi, dan sumbu(X) adalah residual (Y prediksi - Y sesungguhnya) yang telah di-studentized. Data analisisnya, sebagai berikut :

a) Apabila titik-titikmenyebardiatasdandibawahangka (0) pada sumbu (Y) dan tidak membentuk pola tertentu, maka mengindikasikan bahwa tidak terjadi heteroskedastisitas.

b) Apabila titik-titik membentuk pola tertentu yang teratur, maka mengindikasikan bahwa terjadi heteroskedastisitas. Syarat model regresi dapat dikatakan tidak terjadi heteroskedastisitas yaitu apabila signifikansi seluruh variabel independen $>$ 0,05 (Sujarweni, 2015:186-187).

\subsubsection{Uji Autokorelasi}

Uji autokorelasi yaitu keadaan dimana variabel independen mempengaruhi error. Hal ini menyebabkan error pada periode sebelumnya akan mempengaruhi error yang terjadi saat ini sehingga error term akan bernilai lebih rendah yang akan menyebabkan $\mathrm{R}^{2}$ dan Adjusted $\mathrm{R}$ menjadi lebih tinggi. Uji autokorelasi dapat dilakukan dengan cara menghitung nilai durbin-watson statistic, korelasi serial dalam residual tidak terjadi jika nilai (d) berada di nilai batas (du) dan (4-du) (Sujarweni, 2015:186).

\subsubsection{Uji Normalitas}

Pada uji normalitas memiliki kegunaan untuk mengetahui apakah populasi data berdistribusi normal atau tidak (Ghozali, 2016:154). Pada uji normalitas ini pada umumnya digunakan untuk mengukur adat berskala ordinal, interval dan rasio. Uji normalitas dapat dilakukan dengan menggunakan uji statistik non parametik Kolmogrov-Smirnov (K-S), jika nilai signifikan > 0,5 maka data pada penelitian tersebut berdistribusi normal, dan apabila nilai signifikan $<0,5$ maka pada penelitian tersebut tidak berdistribusi normal. Normalitas dalam suatu uji dapat dideteksi juga dengan melihat penyebaran data (titik-titik) pada sumbu diagonal dari grafik yang ada. Apabila data (titik-titk) menyebar mendekati garis diagonal dan mengikuti arah garis diagonal maka menunjukkan membentuk pola distribusi normal yang mempunyai indikasi bahwa model regresi tersebut telah memenuhi asumsi pada uji normalitas. Dan apabila data (titik-titik) menyebar menjauhi dari garis diagonal atau tidak mengikuti 
arah garis diagonal makan tidak menunjukkan membentuk pola distribusi normal yang mempunyai indikasi bahwa model regresi tersebut tidak memenuhi asumsi pada uji normalitas (Sujarweni, 2015:53).

\subsubsection{Uji Analisis Data}

\subsubsection{Regresi Linear Berganda}

Pada analisis regresi linear berganda memiliki kegunaan untuk meramalkan bagaimana keadaan variabel dependen (X) ketika jumlah variabel independen (Y) lebih dari dua (Wiwaha dalam Purnamasri, dkk, 2017). Pada penelitian ini, analisis regresi linear berganda memiliki kegunaan untuk membuktikan seberapa besar hubungan ketiga variabel independen $(\mathrm{X})$ yaitu pengaruh pemahaman wajib pajak $\left(\mathrm{X}_{1}\right)$, sanksi perpajakan $\left(\mathrm{X}_{2}\right)$, dan tingkat kepercayaan pada pemerintah $\left(\mathrm{X}_{3}\right)$ terhadap satu variabel dependen (Y) yaitu terhadap kepatuhan wajib pajak membayar PBB-P2. Persamaan regresinya adalah sebagai berikut :

$\mathrm{KWP}=\alpha+\beta_{1} \mathrm{PP}_{1}+\beta_{2} \mathrm{SP}_{2}+\beta_{3} T K P_{3}+\varepsilon$

(Sugiyono, 2017:275)

Keterangan :

KWP = variabel dependen (kepatuhan wajib pajak membayar PBB-P2)

$\alpha \quad=$ bilangan konstan

$\beta_{1,2,3}=$ koefisien arah garis

$\mathrm{PP}_{1} \quad=$ variabel independen (pemahaman perpajakan)

$\mathrm{SP}_{2}=$ variabel independen (sanksi perpajakan)

$\mathrm{TKP}_{3}=$ variabel independen (tingkat kepercayaan pada pemerintah)

\subsubsection{Koefisien Determinasi $\left(R^{2}\right)$}

Pada penelitian ini untuk menghitung koefisien determinasinya dengan mengunakan rumus yaitu :

$$
\operatorname{RKWP}(1,2,3)=\frac{\mathbf{b}_{1} \Sigma P P_{1} K W P+b_{2} \Sigma S P_{2} K W P+b_{3} \Sigma T K P_{3} K W P}{\Sigma K W P^{2}}
$$

(Sugiyono, 2017:286)

Keterangan $: \operatorname{Ry}(1,2,3)=$ koefisien determinasi antara pemahaman perpajakan, sanksi perpajakan, dan tingkat kepercayaan pada pemerintah dengan kepatuhan wajib pajak membayar PBB-P2. 
Koefisien determinasi mengukur seberapa besar kemampuan dalam dalam menjelaskan variasi variabel nilai R2 yang mendekati 1 artinya ketiga variabel independen yang terdapat dalam penelitian ini memberikan hampir seluruh informasi yang dibutuhkan untuk memprediksi satu variabel dependen yang terdapat dalam penelitian ini.

\subsubsection{Uji Hipotesis}

\subsubsection{1. (Parsial) Uji Statistik $t$}

Pada uji parsial statistik $\mathrm{t}$ dalam penelitian ini memiliki kegunaan yaitu untuk mengetahui pengaruh dari masing-masing ketiga variabel independen $(\mathrm{X})$ terhadap satu variabel dependen (Y) (Ghozali, 2016:78). Pengujian dilakukan dengan menggunakan significance level 0,05 $(\mathrm{a}=5 \%)$. Untuk membandingkan antara t hitung dengan t tabel. Jika t hitung $<\mathrm{t}$ tabel, maka ketiga variabel independen $(\mathrm{X})$ secara individual tidak memiliki pengaruh terhadap satu variabel dependen $(\mathrm{Y})$. Jika $t$ hitung $>\mathrm{t}$ tabel, maka ketiga variabel independen $(\mathrm{X})$ secara individual memiliki pengaruh terhadap satu variabel dependen $(\mathrm{Y})$.

Hipotesis yang diajukan sebagai berikut :

$\mathrm{H} 0=\mathrm{X} 1, \mathrm{X} 2, \mathrm{X} 3=0$, artinya tidak memiliki pengaruh yang signifikan dari ketiga variabel independen $(\mathrm{X})$ terhadap satu variabel dependen $(\mathrm{Y})$. $\mathrm{Ha}=\mathrm{X} 1, \mathrm{X} 2, \mathrm{X} 3 \neq 0$, artinya memiliki pengaruh yang signifikan dari ketiga variabel independen $(\mathrm{X})$ terhadap satu variabel dependen $(\mathrm{Y})$.

Dengan rumus sebagai berikut :

$$
\mathbf{t}=\frac{\mathbf{r} \sqrt{\mathbf{n}-\mathbf{2}}}{\sqrt{1-\mathbf{r}^{2}}}
$$

(Sugiyono, 2017:250)

\subsubsection{2. (Simultan) Uji Statistik Fisher}

Pada uji statistik fisher memiliki kegunaan untuk mengetahui secara simultan antara ketiga variabel independen (X) terhadap satu variabel dependen (Y). Hal tersebut berikutnya akan dikonsultasikan pada $\mathrm{F}$ tabel dengan didasarkan dalam tarif signifikan 5\%. Jika F hitung < F tabel maka tidak memiliki pengaruh yang signifikan antara ketiga variabel independen $(\mathrm{X})$ secara simultan terhadap satu variabel dependen $(\mathrm{Y})$. Perhitungan uji signifikansi koefisien korelasi ganda dapat menggunakan rumus yaitu : 


$$
\mathbf{F}=\frac{\frac{\mathbf{k}^{2}}{\mathbf{k}}}{\frac{1-\mathbf{R}^{2}}{(n-k-1)}}
$$

(Sugiyono, 2017:257)

Keterangan :

$\mathrm{R}=$ koefisien korelasi ganda

$\mathrm{K} \quad=$ jumlah variabel independen

$\mathrm{n} \quad=$ jumlah anggota sampel

\section{HASIL DAN PEMBAHASAN}

\subsection{Gambaran Umum Objek Penelitian}

\subsubsection{Tempat dan Waktu Penelitian}

Gambaran umum objek dalam penelitian ini ialah menjelaskan objek dan subjek penelitian dan menjelaskan karakter responden, dengan mengambil sampel masyarakat yang bertempat tinggal di Kecamatan Jatinegara Jakarta Timur. Pengambilan sampel yang terdapat pada penelitian ini dengan menggunakan simple random sampling, dikatakan simple (sederhana) karena pengambilan anggota sampel dari populasi dilakukan secara acak tanpa memperhatikan strata yang ada dalam populasi itu (Sugiyono, 2017:82). Pengambilan seberapa banyaknya sampel dalam penelitian ini menggunakan rumus slovin dan dari hasil rumus tersebut diperoleh sampel sebanyak 100 responden.

Pengumpulan data dalam penelitian ini dilakukan melalui penyebaran kuesioner penelitian secara langsung yaitu dengan cara mendatangi Wajib Pajak PBB-P2 Kecamatan Jatinegara (responden) dan secara tidak langsung melalui penghubung dengan menitipkannya kepada pak RT (responden). Peneliti telah menyebarkan kuesioner sebanyak 120 kuesioner ke beberapa kelurahan yang terdapat di Kecamatan Jatinegara yang terdiri dari Kelurahan Cipinang Besar Utara, Kelurahan Cipinang Besar Selatan, Kelurahan Cipinang Muara, dan Kelurahan Bidara Cina yang dilakukan pada tanggal 04 Maret sampai dengan 03 April 2019. 
Tabel 4.1

Sampel dan Tingkat Pengembalian Kuesioner

\begin{tabular}{|l|l|c|l|}
\hline No. & \multicolumn{1}{|c|}{ Keterangan } & Jumlah Kuesioner & $\begin{array}{l}\text { Presentase } \\
(\boldsymbol{\%})\end{array}$ \\
\hline 1. & Penyebaran Kuesioner & 120 & $100 \%$ \\
\hline 2. & Kuesioner yang kembali & 100 & $83.33 \%$ \\
\hline 3. & Kuesioner yang tidak kembali & 20 & $16.67 \%$ \\
\hline 4. & Kuesioner yang dapat diolah & 100 & $83.33 \%$ \\
\hline
\end{tabular}

Sumber : data primer yang diolah tahun 2019

Gambaran tentang data sampel yang ada pada tabel 4.1 ialah kuesioner yang telah peneliti sebar ke para responden (Wajib Pajak) sejumlah 120 rangkap, namun yang kembali kepada peneliti hanya 100 rangkap dan yang tidak kembali kepada peneliti sejumlah 20 rangkap atau 16.67\%. Dan kuesioner yang dapat diolah berjumlah 100 rangkap atau sebanyak $83.33 \%$.

\subsubsection{Karakteristik Profile Responden}

Responden dalam penelitian ini adalah para Wajib Pajak yang bertempat tinggal di Kecamatan Jatinegara Jakarta Timur. Berikut iniialah deskripsi tentang data diri responden (Wajib Pajak) yang terdiri dari Umur, Jenis Kelamin, Pendidikan Terakhir, dan Pekerjaan.

Tabel 4.2

Data Statistik Responden (Wajib Pajak) Berdasarkan Umur

\begin{tabular}{|c|l|c|c|c|}
\hline & Frequency & Percent & Valid Percent & Cumulative Percent \\
\hline Valid 21-30 Tahun & 20 & 20.0 & 20.0 & 20.0 \\
31-40 Tahun & 34 & 34.0 & 34.0 & 54.0 \\
41-50 Tahun & 29 & 29.0 & 29.0 & 83.0 \\
51-60 Tahun & 10 & 10.0 & 10.0 & 93.0 \\
61-70 Tahun & 7 & 7.0 & 7.0 & 100.0 \\
Total & 100 & 100.0 & 100.0 & \\
\hline
\end{tabular}

Sumber : Data primer yang diolah tahun 2019

Pada tabel 4.2 menjelaskan bahwa umur responden (Wajib Pajak) yang paling dominan urutan pertama ialah responden (Wajib Pajak) yang berumur 31-40 tahun dengan jumlah 34 orang atau sebesar 34\%. Selanjutnya urutan kedua ialah responden (Wajib Pajak) yang berumur 41-50 tahun dengan jumlah 29 orang atau sebesar $29 \%$. Untuk urutan ketiga ialah responden (Wajib Pajak) yang berumur 21-30 tahun dengan jumlah 20 orang atau sebesar 20\%. Untuk urutan keempat ialah responden (Wajib Pajak) yang berumur 51-60 tahun dengan jumlah 10 orang atau sebesar 10\%. Dan urutan kelima sekaligus terakhir ialah responden (Wajib Pajak) yang berumur 61-70 tahun dengan jumlah 7 orang atau sebesar $7 \%$. 
Tabel 4.3

Data Statistik Responden (Wajib Pajak) Berdasarkan Jenis Kelamin

\begin{tabular}{|c|l|l|c|l|}
\hline & Frequency & Percent & Valid Percent & $\begin{array}{l}\text { Cumulative } \\
\text { Percent }\end{array}$ \\
\hline Valid Perempuan & 58 & 58.0 & 58.0 & 58.0 \\
Laki-laki & 42 & 42.0 & 42.0 & 100.0 \\
Total & 100 & 100.0 & 100.0 & \\
\hline
\end{tabular}

Sumber : Data primer yang diolah tahun 2019

Pada tabel 4.3 menjelaskan bahwa banyaknya responden (Wajib Pajak) yang berjenis kelamin perempuan lebih dominan dibandingkan responden (Wajib Pajak) berjenis kelamin Laki-laki dengan jumlah 58 orang atau sebesar $58 \%$ dan 42 orang atau sebesar $42 \%$.

Tabel 4.4

Data Statistik Responden (Wajib Pajak) Berdasarkan Pendidikan Terakhir

\begin{tabular}{|l|c|c|c|c|}
\hline & Frequency & Percent & Valid Percent & $\begin{array}{c}\text { Cumulative } \\
\text { Percent }\end{array}$ \\
\hline Valid SD & 1 & 1.0 & 1.0 & 1.0 \\
SMP & 7 & 7.0 & 7.0 & 8.0 \\
SMA/SMK/STM/MA & 68 & 68.0 & 68.0 & 76.0 \\
D3 & 2 & 2.0 & 2.0 & 78.0 \\
D4/S1 & 20 & 20.0 & 20.0 & 98.0 \\
S2 & 2 & 2.0 & 2.0 & 100.0 \\
Total & 100 & 100.0 & 100.0 & \\
\hline
\end{tabular}

Sumber : Data primer yang diolah tahun 2019

Pada tabel 4.4 menjelaskan bahwa pendidikan terakhir responden (Wajib Pajak) yang paling dominan urutan pertama ialah responden (Wajib Pajak) yang berpendidikan terakhir Sekolah Menengah Atas/ Sekolah Menengah Kejuruan/ Sekolah Teknik Menengah/ Madrasah Aliyah (SMA/SMK/STM/MA) dengan jumlah 68 orang atau sebesar 68\%. Selanjutnya urutan kedua ialah responden (Wajib Pajak) yang berpendidikan terakhir Diploma Empat atau Strata Satu (D4/S1) dengan jumlah 20 orang atau sebesar 20\%. Untuk urutan ketiga ialah responden (Wajib Pajak) yang berpendidikan terakhir Sekolah Menengah Pertama (SMP) dengan jumlah 7 orang atau sebesar 7\%. Untuk urutan keempat ialah responden (Wajib Pajak) yang berpendidikan terakhir Diploma Tiga (D3) dengan jumlah 2 orang atau sebesar 2\%. Untuk urutan kelima ialah responden (Wajib Pajak) yang berpendidikan terakhir Strata dua (S2) dengan jumlah 2 orang atau sebesar 2\%. Dan yang terakhir urutan keenam ialah responden (Wajib Pajak) yang berpendidikan terakhir Sekolah Dasar (SD) dengan jumlah 1 orang atau sebesar $1 \%$. 
Tabel 4.5

Data Statistik Responden (Wajib Pajak) Berdasarkan Pekerjaan

\begin{tabular}{|l|l|l|l|l|}
\hline & Frequency & Percent & Valid Percent & Cumulative Percent \\
& & & & \\
\hline Valid Buruh & 5 & 5.0 & 5.0 & 5.0 \\
BUMN/PNS/Pensiunan & 8 & 8.0 & 8.0 & 13.0 \\
Dokter/Guru & 3 & 3.0 & 3.0 & 16.0 \\
Karyawan/Pegawai & 40 & 40.0 & 40.0 & 56.0 \\
Swasta & 5 & 5.0 & 5.0 & 61.0 \\
Pedagang & 39 & 39.0 & 39.0 & 100.0 \\
Wiraswasta & 100 & 100.0 & 100.0 & \\
Total & \multicolumn{3}{|c|}{ Sumber : Data primer yang diolah tahun 2019 } \\
\hline
\end{tabular}

Pada tabel 4.5 menjelaskan bahwa pekerjaan responden (Wajib Pajak) yang paling dominan urutan pertama sebagai Karyawan/Pegawai swasta dengan jumlah 40 orang atau sebesar $40 \%$. Selanjutnya urutan kedua pekerjaan responden (Wajib Pajak) sebagai Wiraswata dengan jumlah 39 orang atau sebesar 39\%. Untuk urutan ketiga pekerjaan responden (Wajib Pajak) sebagai BUMN/PNS/Pensiunan dengan jumlah 8 orang atau sebesar 8\%. Untuk urutan keempat pekerjaan responden (Wajib Pajak) sebagai Buruh dengan jumlah 5 orang atau sebesar 5\%. Untuk urutan kelima pekerjaan responden (Wajib Pajak) sebagai Pedagang dengan jumlah 5 orang atau sebesar 5\%. Dan terakhir urutan keenam pekerjaan responden (Wajib Pajak) sebagai Dokter/Guru dengan jumlah 3 orang atau sebesar $3 \%$.

\section{KESIMPULAN}

Dalam penelitian ini memiliki tujuan untuk mengetahui pengaruh pemahaman perpajakan, sanksi perpajakan, serta tingkat kepercayaan pada pemerintah terhadap kepatuhan wajib pajak dalam membayar Pajak Bumi dan Bangunan - Pedesaan dan Perkotaan di Kecamatan Jatinegara. Analisis pada penelitian ini menggunakan metode analisis regresi berganda dan aplikasi program yang digunakan yaitu (SPSS versi 24). Berdasarkan hasil penelitian yang telah dijelaskan pada bab sebelumnya, maka dapat ditarik kesimpulan sebagai berikut :

1) Terdapat pengaruh siginifikan variabel pemahaman perpajakan terhadap kepatuhan wajib pajak dalam membayar Pajak Bumi dan Bangunan - Pedesaan dan Perkotaan di Kecamatan Jatinegara pada tahun 2019. Hal ini ditunjukkan dengan nilai koefisien regresi yang positif sebesar $(0.307)$, nilai $\mathrm{t}_{\text {hitung }}$ leih besar dari nilai $\mathrm{t}_{\text {tabel }}(4.408>$ 
1.98498), dan nilai signifikansi ( $\mathrm{t}$ ) pemahaman perpajakan terhadap kepatuhan wajib pajak dalam membayar PBB-P2 lebih kecil dari nilai signifikansi $(0.000<0.05)$.

2) Tidak terdapat pengaruh signifikan variabel sanksi perpajakan terhadap kepatuhan wajib pajak dalam membayar Pajak Bumi dan Bangunan - Pedesaan dan Perkotaan di Kecamatan Jatinegara pada tahun 2019. Hal ini ditunjukkan dengan nilai koefisien regresi yang negatif sebesar (-0.209), nilai $t_{\text {hitung }}$ lebih kecil dari nilai $\mathrm{t}_{\text {tabel }}(-1.452<$ 1.98489), dan nilai signifikansi (t) sanksi perpajakan terhadap kepatuhan wajib pajak dalam membayar PBB-P2 lebih besar dari nilai signifikansi $(0.150>0.05)$.

3) Terdapat pengaruh signifikan variabel tingkat kepercayaan pada pemerintah terhadap kepatuhan wajib pajak dalam membayar Pajak Bumi dan Bangunan - Pedesaan dan Perkotaan di Kecamatan Jatinegara pada tahun 2019. Hal ini ditunjukkan dengan nilai koefisien regresi yang positif sebesar (0.654), nilai $t_{\text {hitung }}$ lebih besar dari nilai $t_{\text {tabel }}(6.540$ $>$ 1.98498), dan nilai signifikansi (t) tingkat kepercayaan pada pemerintah terhadap kepatuhan wajib pajak dalam membayar PBB-P2 lebih kecil dari nilai signifikansi $(0.000<0.05)$.

4) Terdapat pengaruh signifikansi variabel pemahaman perpajakan, sanksi perpajakan, dan tingkat kepercayaan pada pemerintah terhadap kepatuhan wajib pajak dalam membayar Pajak Bumi dan Bangunan - Pedesaan dan Perkotaan di Kecamatan Jatinegara pada tahun 2019. Hal ini ditunjukkan dengan nilai $F_{\text {hitung }}$ lebih besar dari nilai $F_{\text {tabel }}(28.113>$ 2.70) dan nilai signifikansi (F) pemahaman perpajakan, sanksi perpajakan, dan tingkat kepercayaan pada pemerintah terhadap kepatuhan wajib pajak dalam membayar PBBP2 lebih kecil dari nilai signifikansi $(0.000<0.05)$.

\section{DAFTAR PUSTAKA}

Mardiasmo. 2018. Perpajakan Edisi Revisi. Jakarta : Penerbit ANDI.

Pengertian Pajak Daerah. 2018. Diunduh pada tanggal 15 November 2018. www.onlinepajak.com

Jati, I. G. 2016. Pengaruh Sikap, Kesadaran Wajib Pajak dan Pengetahuan Perpajakan pada Kepatuhan Membayar Pajak Bumi dan Bangunan. E- Journal Akuntansi Universitas Udayana, Hal. 1510-1535.

Widiastuti, Riana dan Laksito, Herry. 2014. Faktor -Faktor Yang Mempengaruhi Kepatuhan Pajak Bumi Dan Bangunan (P-2) (Studi pada WPOP di Kabupaten Klaten). Journal Of Accounting. Vol. 3. No. 2. Hal. 1-15.

Yusnidar, Johan., Sunarti dan Prasetya, Arik. 2015. Pengaruh Faktor-Faktor Yang Mempengaruhi Kepatuhan Wajib Pajak Dalam Melakukan Pembayaran Pajak 
Bumi Dan BANGUNAN Perdesaan Dan Perkotaan (Studi Pada Wajib Pajak

PBB-P2 Kecamatan Jombang Kabupaten Jombang). Jurnal

Perpajakan

(JEJAK). Vol. 1. No. 1. Hal. 1-10. 